\author{
Nina Pluta (iD) https://orcid.org/0000-0001-7333-9636 \\ Uniwersytet Pedagogiczny im. KEN w Krakowie \\ nina.podleszanska@up.krakow.pl
}

\title{
Vargas Llosa i tubylcy. O poznaniu Innego dla siebie samego
}

\section{Vargas Llosa and the Natives. On the Understanding the Other for Yourself}

\begin{abstract}
In the following text I take a closer look at the tension that arises between postcolonial themes and the tradition of the novel focused on the internal transformation of a white hero in two books by Mario Vargas Llosa, The Way to Paradise (2003) and The Dream of the Celt (2010). Both of these novels feature historical personas, the painter Paul Gauguin and the Irish patriot Roger Casement - two Europeans who traveled to colonial territories at the turn of the $20^{\text {th }}$ century. In both novels natives play a subservient role towards the European heroes: literally, adopting a subordinate stance towards them; and at the plot level, as coming in contact with them is the catalyst of the protagonists' internal transformation. I briefly explain the special situation of Latin American intellectuals, whose cultural ties with the former empire are stronger than in other colonial regions. Next, I comment on the relationship between Europeans and natives, arguing that the postcolonial character of Vargas Llosa's novel is limited, paradoxically, by the successful and enjoyable implementation of the traditional European narrative in which the hero's visions and plans come into conflict with the outside world.
\end{abstract}

Keywords: Latin American literature in the $20^{\text {th }}$ and $21^{\text {st }}$ centuries, postcolonial novel, Mario Vargas Llosa, depictions of the Other

Streszczenie: W poniższym tekście przyglądam się napięciu, które tworzy się między tematyką postkolonialną a tradycją powieści skupionej na przemianach wewnętrznych białego bohatera w dwóch książkach Maria Vargasa Llosy:Raju tuż za rogiem (2003) i Marzeniu Celta (2014). W obu tych powieściach występują postacie historyczne (malarz Paul Gauguin i irlandzki patriota Roger Casement), Europejczycy, którzy podróżują do terytoriów kolonialnych na przełomie XIX i XX wieku. Także w obu tubylcy pełnią wobec europejskich bohaterów funkcję służebną: zarówno dosłownie, zajmując wobec nich pozycję podległą, jak i na poziomie fabuły - kontakt z nimi katalizuje przemiany wewnętrzne głównych bohaterów. Wyjaśniam skrótowo szczególną sytuację intelektualistów hispanoamerykańskich, których więź kulturowa z dawnym imperium jest silniejsza niż w innych rejonach kolonialnych. Następnie komentuję relację Europejczyk-tubylcy, dowodząc, że postkolonialny charakter powieści Vargasa Llosy jest ograniczony, poprzez, paradoksalnie, udaną i atrakcyjną realizację schematu tradycyjnej powieści europejskiej, w której wizje i plany bohatera wchodzą w konflikt ze światem zewnętrznym. 
Słowa kluczowe: literatura hispanoamerykańska XX-XXI wiek, powieść postkolonialna, Mario Vargas Llosa, przedstawienie Innego

Kiedy „Imperium oddaje cios” za pomocą literatury, jak głosi tytuł jednej z kanonicznych lektur literaturoznawczych w dziedzinie studiów postkolonialnych ${ }^{1}$, robi to, nie tylko przedstawiając losy skolonizowanych autochtonów, lecz także skupiając się na mentalności i przemianach wewnętrznych, jakim ulegają Europejczycy pod wpływem doświadczeń na peryferiach dawnych imperiów. Tradycję zapoczątkowuje Jądro ciemności Conrada. Utwory te pokazują dawnym hegemonom ich własny wizerunek, odarty z aury, jakiej przydaje władza. Te literackie sylwetki Europejczyków to szczególne „przesyłki zwrotne”, jakie społeczeństwa postkolonialne adresują do dawnych metropolii. Nie tubylec, lecz właśnie przybysz z Europy przeżywa tu rozterki, kryzysy osobowości i alienację.

Zasadniczo zgadzam się z Katarzyną Mroczkowską-Brandt na temat użyteczności, czy też staromodnie brzmiącego obowiązku moralnego, czytania o doświadczeniach i historii grup ludzkich dotkniętych tragicznymi konsekwencjami kolonizacji. Zwracam jednak uwagę, że tak zwana literatura postkolonialna bardzo często opowiada o sprzecznych i bolesnych przeżyciach samych Europejczyków mierzących się z własnym odbiciem w krzywym zwierciadle przemocy. Wtedy pojawia się też pytanie, w jakim stopniu literackie sposoby odnoszenia się do świata wykształcone w Europie są w stanie oddać sprawiedliwość losom innych cywilizacji - Katarzyna Mroczkowska-Brand nazywa to odzyskiwaniem zawłaszczonej reprezentacji. O tym między innymi mówi poniższy tekst.

Chciałabym podjąć mniej typowy wątek tematyczny w literaturze postkolonialnej, która okazuje się nie tylko zapisem krzywd fizycznych i psychicznych wyrządzonych ludności większej części świata przez Europejczyków, lecz także świadectwem postaw, wcale niejednoznacznych, zajmowanych przez „białego człowieka” wobec imperialnego porządku na peryferiach i wobec jego mieszkańców. Prześledzę ten temat w dwóch powieściach peruwiańskiego noblisty Maria Vargasa Llosy, Raj tuż za rogiem (2003) $)^{3}$ i Marzenie Celta $(2010)^{4}$. W rezultacie swoich doświadczeń w kolonialnym świecie i kontaktów (również seksualnych) z tubylcami bohaterowie tych powieści, Paul

${ }^{1}$ B. Ashcroft, G. Griffiths, H. Tiffin, The Empire Writes Back. Theory and Practice in Post-Colonial Literatures, London-New York 1989.

${ }^{2}$ Ewa Łukaszyk używa tego określenia, mając na myśli etap postkolonialnych rozrachunków, kiedy to do kolonizatora adresuje się „żale w swoim czasie niewypowiedziane”. Taż, Od podlegtości do horyzontalnego diagramu relacji. Studium relacji transkolonialnych [w:] Debaty Artes Liberales, t. 10: Perspektywy postkolonializmu w Polsce, Polska w perspektywie postkolonialnej, red. J. Kieniewicz, Warszawa 2016, s. 95-96.

${ }^{3}$ M. Vargas Llosa, Raj tuż za rogiem, tłum. D. Rycerz, Kraków 2010. Wszystkie cytaty pochodzą z tego wydania polskiego.

${ }^{4}$ Tenże, Marzenie Celta, tłum. M. Chrobak, Kraków 2016. Wszystkie cytaty pochodzą $\mathrm{z}$ tego wydania polskiego. 
Gauguin i Roger Casement, notabene postacie historyczne, odkrywają, już jako dorośli, nowe aspekty własnej tożsamości i nowe, nieznane im wcześniej formy pożądania. W przebiegu tego procesu ujawniają się napięcia typowe dla sytuacji kolonialnej opresji i dotykające tak podległych, jak sprawujących władzę, oczywiście z dotkliwszymi skutkami dla tych pierwszych. Odwołam się w analizie do rozważań na temat typowych dla kondycji kolonialnej sprzeczności, alienacji i zaburzeń tożsamości w wymiarze indywidualnym i zbiorowym, autorstwa między innymi Frantza Fanona, Homiego Bhabhy i Achillego Mbembe; również do latynoamerykańskich teoretyków „dekolonializmu”, którzy, podobnie jak Mbembe w opisie „nekropolityki”, upatrują w dzisiejszych światowych kryzysach i zagrożeniach konsekwencje tego, że przez ponad cztery wieki kolonialna władza, interesy i dyskursy determinowały ekonomiczne i społeczne stosunki globalne, w tym stosunek ludzi białych do tak zwanego Innego.

Szczególna sytuacja literatury hispanoamerykańskiej, która od połowy XX wieku zredagowała dużo wspomnianych wcześniej „przesyłek zwrotnych” o podboju i kolonizacji, polega na tym, że większość autorów była i jest w Ameryce Hiszpańskiej biała. Zatem „rozliczając” okres kolonialny i jego skutki, nie potrafili oni radykalnie odciąć się od swego na poły uznanego, a na poły zakwestionowanego (po uzyskaniu niepodległości) dziedzictwa - od języka, konwencji, stylów artystycznych rodem z Europy, zaadaptowanych w Ameryce. Przestrzeń kultury hispanoamerykańskiej tworzą rozmaite mieszanki i amalgamaty tradycji kreolskiej, indiańskiej, metyskiej i afrykańskiej. W XIX wie$\mathrm{ku}$, mimo uzyskania niepodległości politycznej, kolonialne stosunki społeczne, rasowe i ekonomiczne, oparte na wyzysku i rasizmie, nie uległy znaczącej zmianie; do dziś przetrwało wiele schematów marginalizujących duże grupy ludności. W tej przestrzeni mogło - i może nadal - dochodzić do podobnych rozdarć tożsamościowych, jak te, które ponad pół wieku temu opisywał Fanon w Peau noire, masques blancs (1952) i Wyklętym ludzie ziemi (1962), określając stosunki społeczne w kolonialnej Afryce Północnej następująco:

5 Od lat osiemdziesiątych XX wieku teoretycy z nurtu tak zwanej myśli dekolonialnej (wywodzący się z Ameryki Łacińskiej lub skupieni na niej) rozpatrują wpływające na świat do dziś różne odmiany kolonialności (na płaszczyźnie rasy, władzy, wiedzy, egzystencji). Są to kształtowane od XVI wieku matryce europejskiego stosunku do Innego, przy czym stosunek ten jest nieodłączny od - ujmowanych w skali globalnej - prawnych, politycznych, religijnych, naukowych i ekonomicznych uwarunkowań rozwoju europejskiego projektu modernizacji, de facto kapitalizmu. Zob. między innymi W.D. Mignolo, The Darker Side of the Renaissance. Literacy, Territoriality, and Colonization, Ann Arbor 1995; tenże, Historias locales/diseños globales. Colonialidad, conocimientos subalternos y pensamiento fronterizo, tłum. na j. hiszp. J.M ${ }^{a}$ Madariaga, C. Vega Solís, Madrid 2003; A. Quijano, Colonialidad del poder, eurocentrismo y América Latina [w:] La colonialidad del saber: eurocentrismo y ciencias sociales. Perspectivas latinoamericanas, red. E. Lander, Buenos Aires 2000, http://bibliotecavirtual.clac-so.org.ar/ar/libros/lander/ quijano.rtf, dostęp: 17.06.2019; E. Dussel, Hacia una filosofía politica crítica, wprowadzenie E. Mendieta, Bilbao 2001. 
alienacja, neuroza, swoista schizofrenia, przywiązanie, a jednocześnie lekceważenie własnej kultury.

Nie jest też oczywiście tak, że Vargas Llosa, Kreol z klasy średniej, uprawia rewizjonizm, uwypuklając niedole Białych, kosztem prawdy o skolonizowanych. W analizowanych powieściach europejscy bohaterowie doznają przemian, stykając się z „rzeczywistym” - cierpieniem całych rzesz ludzkich, okrucieństwem, opresją. W Raju tuż za rogiem i Śnie Celta w jakiejś mierze mamy więc do czynienia z odmianą uniwersalnej opowieści o dochodzeniu do świadomości zła w świecie na skutek poznawczej i moralnej traumy. Vargas Llosa wnika umiejętnie w stan permanentnego napięcia, które w społeczeństwach kolonialnych ogarnia i panujących, i podległych. Jak można się spodziewać, biali bohaterowie przeżywają burzę ambiwalentnych doznań w stosunku do Innych: od lekceważenia i niezrozumienia, poprzez zainteresowanie, współczucie i wstyd, po ekscytację seksualną i pragnienie identyfikacji. To ostatnie skazuje ich jednak, wedle logiki kolonialnej kondycji, na wieczne oddzielenie (i od Ja, i od Innego) i bytowanie „pomiędzy”. Zrozumienie niuansów i ambiwalencji kolonialności w stosunkach politycznych i społecznych z pewnością zawdzięcza Vargas Llosa także własnemu doświadczeniu białego pisarza należącego do elity intelektualnej w kraju, w którym Biali stanowią co najwyżej 15\% ludności. W Hispanoameryce owa piśmienna elita („miasto piśmienne”, ciudad letrada, według znanego określenia Angela Ramy) utrzymuje się od czasów kolonialnych blisko kręgów władzy i wywiera decydujący wpływ na wypełnianie symbolicznej przestrzeni „wspólnoty wyobrażonej”. Twórcy nowoczesnej kultury hispanoamerykańskiej byli - i są nadal, chcąc nie chcąc - w większości spadkobiercami kolonizatorów z Europy. Mimo symbolicznych gestów negowania hiszpańskiej spuścizny Kreole nie odbierali języka hiszpańskiego jako narzuconego w taki sposób, w jaki mógł to odczuwać Afrykańczyk wobec francuskiego czy Hindus - angielskiego ${ }^{7}$. Mnoży to problemy etyczne i estetyczne, gdy przychodzi do przedstawiania innych, nieeuropejskich kultur, ale faktem pozostaje, że wybijając się na niepodległość, Kreole, owszem, odcięli pępowinę, nie musieli natomiast całościowo zmieniać skóry ${ }^{8}$.

${ }^{6}$ H.K. Bhabha, Location of Culture, London-New York 1994, s. 45.

7 Hispanoamerykańskie „wspólnoty wyobrażone” powstawały w procesie nieco odmiennym od europejskiego. W konstytuowaniu nowych państw, sprzężonych z pojęciem narodu, udział klas ludowych i niższych klas średnich był o wiele mniejszy, poza tym przejęto język kolonizatora. Zob. B. Anderson, Wspólnoty wyobrażone. Rozważania o źródtach i rozprzestrzenianiu się nacjonalizmu, tłum. S. Amsterdamski, Kraków 1997, szczególnie rozdz. IV: Kreolscy pionierzy.

${ }^{8}$ Intelektualista podległego kraju (Fanon myśli o krajach afrykańskich) przejmuje wzorce kultury europejskiej za cenę zmiany skóry, rozdarty między fascynacją kulturą kolonizującego a potrzebą umocnienia rdzennej tożsamości. Zob. F. Fanon, Wyklęty lud ziemi [1961], tłum. H. Tygielska, przedm. E. Rekłajtis, posł. J.-P. Sartre, Warszawa 1985, s. 149 i n. 


\section{Tropiki i witalność artysty. $R a j$ tuż za rogiem}

W biografii pisarza Vargasa Llosy zasadniczą rolę odegrały inspiracje europejskie, a przede wszystkim tradycja XIX-wiecznego realizmu. W tym sensie Peruwiańczyk nie problematyzuje kwestii „zawłaszczania reprezentacji”, czyli podporządkowania opowieści o koloniach „perspektywie sił kolonizujących”, co wymieniane jest jako jeden z podstawowych dylematów literatury postkolonialnej’. Jego powieści są dobrze udokumentowane w sferze faktów i obyczajowości, a ich akcja trzyma się formuły wywiedzionej z lektury Flauberta: „Powieść jest (...) tym bardziej pociągająca, gdy łączy, starannie dobrane i zmieszane w zwartej opowieści, następujące składniki: bunt, przemoc, melodramat i seks" ${ }^{10}$. Przemiany zarówno Gauguina, jak i Casementa podczas pobytu w koloniach, układają się w szerszy schemat poznawczy, który można odnaleźć na wielu etapach rozwoju nowoczesnej powieści zachodniej, od sentymentalnej, poprzez romantyczną, Bildungsroman i realizm, po modernistyczną biografię artysty czy intelektualisty. Schemat ten wyznacza drogę kształtowania się jednostki, która dostraja swoje poczucie wolności do świata, przy czym ważną rolę odgrywa sfera jej subiektywności ${ }^{11}$. Llosa wykorzystuje więc sprawdzone na gruncie europejskim konwencje gatunkowe, nie dążąc do ich „anulowania” $(\text { abrogation })^{12}$. Obie powieści wykazują w związku z tym interesującą ambiwalencję. $\mathrm{Z}$ jednej strony poprzez ukształtowanie losów bohaterów (ich bolesne przemiany w starciu z własnymi wyobrażeniami i ze światem zewnętrznym) potwierdzają hegemonię europocentrycznego podmiotu. $Z$ drugiej opowiadają o okrucieństwie, jakie dotknęło tubylców i oddają atmosferę epoki, w której budził się protest przeciwko imperialistycznej organizacji świata.

Zwracając uwagę na fakt, że Vargas Llosa ma podstawy, żeby rozumieć Europejczyków i w ogóle Białych, nie pomijam znaczenia jego innych powieści, w których pojawiają się Indianie, Afroamerykanie i postacie z różnych klas społecznych. Wielokrotnie modeluje on bohaterów żyjących w podległości i porusza kwestie dotyczące ich kondycji ${ }^{13}$. Niemniej zarzucano mu skądinąd, że przedstawiając Indian, nie uwzględnia należycie realiów ekonomicznych (konflikty

9 K. Mroczkowska-Brand, Postkolonialna lekcja uważności, „Konteksty Kultury” 2019, nr 3, s. 299-323.

${ }^{10}$ M. Vargas Llosa, La orgía perpetua. Flaubert y „Madame Bovary”, Barcelona 1975, s. 20 [tłum. własne - N.P.]. Cytowane źródło jest zarazem doktoratem Vargasa Llosy.

${ }_{11}$ Wolność podmiotu jest też jednym z fundamentów ideologii kapitalizmu, a wyrażeniu jego wewnętrznej prawdy i jego subiektywności służy nowoczesna literatura europejska. J.C. Rodríguez, De qué hablamos cuando hablamos del marxismo, Madrid 2013, s. 70-72.

${ }^{12}$ B. Ashcroft, G. Griffiths, H. Tiffin, dz. cyt., s. 90-96.

${ }_{13}$ Wątek Bonifacii w Zielonym domu, Ambrosia w Rozmowie w Katedrze, postacie z powieści Wojna końca świata, Gawędziarz, Historia Mayty czy Lituma w Andach; również w Raju tuż za rogiem i Marzeniu Celta liczne epizody dotyczą postkolonialnych konfliktów społecznych. 
wokół własności ziemi) ${ }^{14} \mathrm{i}$ że popada w stereotypy bliskie rasizmowi (Indianie zacofani i barbarzyńscy $)^{15}$. Nie zamierzam jednak analizować wszystkich wariantów motywu Innego w twórczości tego pisarza, lecz skupić się na wspomnianych powieściach, które, według logiki powieści zachodniej, organizują narrację wokół kolei losu i życia wewnętrznego Europejczyka.

Czego chce czarny człowiek? - pytał Fanon ${ }^{16}$, szukając drogi do emancypacji skolonizowanego Afrykanina i śledząc ekonomię jego snów, pragnień, afektów, popędów oraz jego kompleksy i ambiwalencję w stosunku do kolonizatorów. We wspomnianych powieściach Vargas Llosa przekazuje to pytanie Europejczykom, którzy przebywając w rzeczywistości (post)kolonialnej, prędzej czy później, ulegają mechanizmom socjopsychologicznym, takim jak ambiwalentna potrzeba identyfikacji z Innym. W przypadku Europejczyków jest to Inny pociągający egzotyką i aurą pierwotnej żywotności, ale też groźny: w różnicach wymykających się sztywnemu stereotypowi, w swym naśladownictwie zachowania kolonizatora i hybrydycznej interpretacji jego dyskursu, podważających jednoznaczność władzy ${ }^{17}$, wreszcie w tej nieuchwytnej części swej osoby, która może się okazać częścią wspólną wszystkim ludziom, naruszając hierarchię i kolonialny porządek. W powieściach Vargasa Llosy wyczytujemy zatem, jak bohaterowie, Paul Gauguin i Roger Casement, dochodzą do tego, „czego chcą" oni sami w tym samym czasie, w którym zaczynają zastanawiać się - nie zawsze dobrze to odgadując - co czują i czego chcą skolonizowani. Z różnych powodów - wrażliwości, ekstrawagancji, artystycznej wizji, preferencji seksualnej czy przekonań politycznych - obaj są w pewnym sensie wyalienowani ze swojego otoczenia. Ich własne dylematy tożsamościowe - sny, pragnienia, seksualność - zaczynają jawić się im w innym świetle, gdy opuszczając rodzime wspólnoty, zanurzają się w świat zmasowanego cierpienia.

Paul Gauguin i Roger Casement są postaciami historycznymi. Obaj żyli i działali na przełomie XIX i XX wieku, obaj podróżowali na „peryferia” ówczesnych imperiów kolonialnych. Pierwsza powieść przedstawia, dwutorowo, życie francuskiej działaczki socjalistycznej Flory Tristan oraz jej wnuka, malarza Paula

${ }^{14} \mathrm{M}^{a}$. de las M. Ortiz Rodríguez, La fisura irremediable: indígenas, regiones y nación en tres novelas de Mario Vargas Llosa, „Antípoda: Revista de Antropología y Arqueología” 2012, nr 15, s. 116, http://dialnet.unirioja.es/descarga/articulo/4085032.pdf 2012, dostęp: 21.06.2019.

${ }_{15}$ M. Kokotovic, Vargas Llosa in the Andes: The Racial Discourse of Neoliberalism, „Confluencia" 2000, nr 2, s. 156-167, www.jstor.org/stable/27922749, dostęp: 20.06.2019; I. López-Calvo, El anti-indigenismo en "El hablador” y „Lituma en los Andes”, de Mario Vargas Llosa, „Desde el Sur" 2009, nr 2, s. 237-262; J.C. Piñeyro, La construcción de la alteridad en "Lituma en los Andes”, „Studia Neophilologica” 2014, nr 2, s. 99-119.

${ }^{16}$ F. Fanon, Piel negra, máscaras blancas (oryg. Peau noire, masques blanches, 1952), tłum. na hiszp. A. Useros Martín, Madrid 2009, s. 41.

17 H.K. Bhabha, Of Mimicry and Man: The Ambivalence of Colonial Discourse, „October” 1984, nr 28, s. 132, www.jstor.org/stable/778467, dostęp: 24.07.2019; tenże, Signs Taken for Wonders: Question of Ambivalence and Authority under a Tree outside Dehli, May 1817 [w:] tegoż, Location of Culture, dz. cyt. 
Gauguina, który drugą część życia spędził na wyspach Polinezji Francuskiej. Skupię się tutaj na wątku Gauguinowskim (choć tematy idealizmu, utopizmu i dyskryminacji wyłaniają się z obu biografii). Bohaterem drugiej jest Roger Casement, Irlandczyk, który najpierw jako brytyjski dyplomata sporządzał raporty o okrutnym traktowaniu rdzennych mieszkańców Kongo i Amazonii, a później został bojownikiem o wolność własnej ojczyzny. Akcja obu powieści osadzona jest w epoce, w której w naukach i sztukach europejskich budzi się fascynacja pierwotnymi kulturami obu Ameryk, Afryki czy Dalekiego Wschodu. W malarstwie Gauguina, w późniejszych awangardach, a także w literaturze latynoamerykańskiej pierwszych dekad XX wieku (powieści indygenistycznej, poezji negroantylskiej) następowała symboliczna rehabilitacja ludzi innych ras. We wspomnianych powieściach słychać również głosy krytyki wobec szkód, jakie w skali globu wyrządzały kolonialny imperializm i dziki kapitalizm, co współbrzmi z podobną problematyką we współczesnych debatach. Zarówno ze względu na temat (interakcje między podmiotami podległymi i hegemonicznymi), jak i na kryterium terytorialno-historyczne (autor pochodzi z dawnych kolonii) ${ }^{18}$ powieści Vargasa Llosy można zaliczyć do literatury postkolonialnej. W poniższym tekście chciałam jednak pokazać, że mimo spełnienia tych kryteriów są one bardzo silnie osadzone w tradycji nowoczesnej powieści europejskiej (od XVII wieku) i że przedstawienie Innego (podległego, marginalizowanego, pozbawionego głosu) służy w nich przede wszystkim uwydatnieniu ewolucji wewnętrznej białego bohatera. Użyty czasownik jest dwuznaczny: tubylec (Tahitanka, szaman z Markizów, Indianin czy polinezyjski dwupłciowy mahu) służy w obu powieściach Vargasa Llosy w sensie dosłownym - bo jest osobą służebną, na przykład obiektem seksualnym czy pomocą domową - oraz w sensie przenośnym - katalizuje przemiany Europejczyka w narracji opowiadającej o rozwoju tego ostatniego.

Wątek Gauguina w Raju tuż za rogiem zaczyna się na Tahiti, w 1892 roku, a kończy wraz z jego śmiercią na wyspie Hiva Oa w archipelagu Markizów, gdzie umiera w roku 1905. Koleje jego życia są stopniowo uzupełniane w obszernych retrospektywach. Gauguin pojechał na peryferia imperium, by spełniać się jako malarz - jak wiadomo, został nim znacznie po trzydziestce, gdy porzucił żonę z pięciorgiem dzieci i karierę finansisty. Tahiti interesuje go nie jako złożony kulturowo i pełen konfliktów świat (choć okazjonalnie włącza się w lokalne życie, prowokując skandale), lecz przede wszystkim jako zespół podniet pobudzających proces twórczy:

Jechał tu pełen złudzeń. Ledwie zaczerpnął w płuca gorącego powietrza Papeete, od razu oślepiło go silne światło bijące z intensywnie błękitnego nieba i poczuł wokół siebie bliskość przyrody o niezwykłej obfitości drzew owocowych, które były wszędzie obecne i nasycały zapachami zakurzone uliczki miasta: drzewa pomarańczowe, cytrynowe, palmy kokosowe, mangowce, bujne gwajakowce i gęste drzewa

18 B. Ashcroft, G. Griffiths, H. Tiffin, dz. cyt., s. 1-2. 
chlebowe; wtedy ogarnęła go tak wielka ochota, by zabrać się do pracy, jakiej od dawna nie odczuwat ${ }^{19}$ [podkr. moje - N.P.].

Powyższy fragment jest daleką reminiscencją przygody poznawczej Kolumba i innych autorów tak zwanych tekstów pierwszego kontaktu. Pragnienie odnalezienia ziemi obiecanej, raju czystego i pierwotnego, dalekiego od europejskiej cywilizacji, jest tak silne, że działa jak samospełniająca się przepowiednia. $\mathrm{Na}$ Tahiti Gauguin tropi przejawy pierwotnej kultury - tajemnica obojnaczych mahu, tajne stowarzyszenie ludu Ariori skupiające „bogów i władców dawnych Tahitańczyków” ${ }^{20}$, pradawna sztuka tatuażu - wzmagające w nim tęsknotę za dzikim Maorysem, „po którym wkrótce, za sprawą Europy, nie będzie ani śladu"21. W jego projekcjach odnajdujemy przedawangardowy postulat jedności życia, sztuki i religii. Splata się on dodatkowo z wątkiem seksualności, którą bohater chce wyrażać „bez żadnych ograniczeń”, jako że jest zwolennikiem „miłości we wszystkich jej odmianach, łącznie z biseksualizmem”22. Gauguin kieruje się sygnałami z tych pokładów ludzkiej osobowości, które na przełomie wieków badał Freud, kładąc podwaliny pod psychologię głębi:

Namalowałeś najlepszy obraz nie tylko swoimi dłońmi, wykorzystując własne idee, własną fantazję, dobre rzemiosło. Także za pomocą ciemnych sił, wydobytych z głębi duszy, chaosu twoich namiętności, furii twoich instynktów, impulsów ${ }^{23}$.

Cała ta energia potrzebuje ujścia. Nigdzie lepiej nie ujawnia się dwuznaczność Gauguinowskich fantazji o archaicznych królestwach sztuki i nieskrępowanej radości ciała jak w odmalowanym w powieści z realistyczną „bezstronnością” stosunku artysty do polinezyjskich kobiet. Czasem narracja sygnalizuje dyskretnie, że te czternastoletnie lub niewiele starsze kochanki Gauguina miały swoje zdania, plany i interesy, przeważnie jednak widzimy je tak, jak postrzega je bohater, jako narzędzia jego spełniania się w różnych sferach życia:

Dziewczyna była dla niego niewyczerpywalnym źródłem rozkoszy. Gotowa oddawać się, kiedy tylko pragnął, nie grymasiła i także znajdowała w tym przyjemność, z pełnią swobody i zachęcającej radości (...). Poza tym była gospodarna ${ }^{24}$.

19 M. Vargas Llosa, Raj tuż za rogiem, dz. cyt., s. 22.

20 Tamże, s. 158.

${ }^{21}$ Tamże, s. 409. Sam Vargas Llosa zabierał głos, jako pisarz, eseista i publicysta, w sprawie granic nieingerencji w życie ostatnich wspólnot i plemion pierwotnych. Rozumiejąc nostalgię obrońców „czystości” kultur (powieść Gawędziarz z 1987 czy esej La utopia arcaica. José María Arguedas y las ficciones del indigenismo z 1996), stoi jednak na stanowisku, że powrót do pierwotnego raju indiańskiego jest niemożliwy. Zauważa też, że pod pretekstem jego przywrócenia forsowano rozwiązania, które w sumie bywały reakcyjne, a nie emancypacyjne.

${ }_{22}$ M. Vargas Llosa, Raj tuż za rogiem, dz. cyt., s. 235.

23 Tamże, s. 236-237.

${ }^{24}$ Tamże, s. 27. 
Znamienny jest epizod, w którym Teha'amanę paraliżuje strach przed nocnym duchem. Gdy Gauguin tuli ją i uspokaja, przez głowę przelatuje mu lawina skojarzeń kulturowych. Nagle dociera do niego, że napad lęku u dziewczyny dowodzi żywotności dawnych wierzeń, i wtedy ogarnia go podniecenie erotyczne: przez krótką chwilę, „kiedy dokonywał gwałtu na Teha’amanie, poczuł się dzikusem”25. Owo chwilowe utożsamienie się „pana” z „niewolnikiem” wpisuje się w kolonialną logikę ambiwalentnych pragnień, w której kolonizujący podporządkowuje rozliczne odmiany stereotypu Innego swoim fantazjom, tak długo, jak wpływają one korzystnie na jego własny narcystyczny wizerunek - w tym wypadku związany z poczuciem mocy twórczej. Gauguin wpuszcza wprawdzie tubylców do swojego domu i w oczach innych Białych w sposób skandaliczny zaciera różnice rasowo-klasowe, jednak kluczem do obcowania z Innym są tu jego prywatne wyobrażenia o pierwotnej czystości, mityczno-bajkowe stereotypy, które bardzo umownie przybliżają tubylczą kulturę, bo przede wszystkim umożliwiają cyrkulację dyskursu kolonialnego, umacniającego sprawowanie władzy ${ }^{26}$.

Po pamiętnej nocy z duchem Gauguin namaluje obraz zatytułowany $\mathrm{Ma}$ nao tupapau (Duch zmarłych czuwa). Religia, życie i seksualność rzeczywiście współistnieją w takich momentach olśnienia - ale nie w przestrzeni jakiegoś raju, lecz w głowie bohatera. Gdy natomiast rzeczywistość skrzeczy - syfilis odbiera zdrowie, a pieniędzy brak - tytułowy „raj” objawia symptomy degradacji: „Tak więc również tutaj, mimo pięknych krajobrazów, tubylczej ludności, skromnych resztek tego, czym była kiedyś płodna cywilizacja Maorysów, pieniądz rządził ludzkim życiem i śmiercią" ${ }^{27}$. Wtedy polinezyjskie partnerki drażnią go, ciążą mu, dostrzega u nich brak polotu intelektualnego.

Choć podziwia Maorysów i sam pragnie zostać „dzikusem”, jest oczywiste, że na użytek swojej artystycznej wizji dowolnie interpretuje ich kulturę:

Koke, Koke, właśnie ty powinieneś odtworzyć tę unicestwioną kulturę, aby nadal mogła istnieć. Czy Maorysi byli kiedykolwiek podobni do tych, którzy pojawili się na Twoim obrazie? Naturalni, przyjaźni wobec własnych ciał, zbratani z drzewami, które ofiarowały im owoce (...), a po morzu śmigali zwinnymi łodziami, chronieni przed nieszczęściem przez intrygującą boginię Hinę, którą także powinieneś dla nich odtworzyć, bo żaden Tahitańczyk teraz już nie pamięta, jak wyglądała ${ }^{28}$.

Poszukiwanie raju przez Gauguina ma charakter fantazmatyczny i eskapistyczny, to miejsce nieosiągalnej doskonałości, którą usiłuje osiągnąć

25 Tamże, s. 31.

26 H.K. Bhabha, Location of Culture, dz. cyt., s. 66-74. Stereotyp pociągający i odpychający zarazem jest zabiegiem konstytuującym kolonialny dyskurs o podmiotowości.

27 M. Vargas Llosa, Raj tuż za rogiem, dz. cyt., s. 40.

28 Tamże, s. 236. 
w kontaktach z maoryskimi kobietami, a także przez próby dotarcia do tajemnych rytuałów i miejsc inicjacji, do których dostęp jest dla niego tak trudny, bo być może to w dużej mierze płody jego wyobraźni. Negacja różnicy poprzez stereotyp nie ma tu jednak na celu, jak sugeruje Bhabha (zob. przyp. 37), usztywnienia i wyparcia popędów - te wydobywają się bez przeszkód na powierzchnię u temperamentnego artysty - służy mu natomiast okazjonalnie do bezkrytycznego ucieleśniania własnych tęsknot do pełni.

Tubylcy, którzy mu pozują, nie rozpoznają samych siebie na obrazach. Z kolei Gauguin, chcąc się do nich upodobnić, zapuszcza włosy, chodzi ubrany w pareo, przeżywa przygodę seksualną z dwupłciowym mahu, rzeźbi wizerunki tubylczych bogów. Jest to ciekawy przykład mimikry kolonialnej opisywanej przez Homiego Bhabhę, tutaj występującej à rebours: to nie Inny podejmuje naśladownictwo, aby upodobnić się do obcej kultury, lecz Europejczyk jest tym, kto się przebiera, by zostać Innym. Ambiwalencja mimikry - prawie taki sam, ale nie zupełnie - prowadzi do częściowej tylko reprezentacji obiektu, do jego przemieszczenia, popadnięcia w budzącą niesmak (zarówno u Białych, jak u tubylców) groteskę ${ }^{29}$. Sztuczność postawy Gauguina jest tu podwójna: po pierwsze, strój nadający mu cudaczny wygląd, po drugie, sztuczna relacja „podległości” rdzennej kulturze, której nie może przecież nawiązać, bo ostatecznie jest on ciągle przedstawicielem kolonizatora. Jego „hybrydyczność” okazuje się zatem pozorna, gdyż nie narusza systemu kolonialnych różnic, naznaczając je ambiwalencją ${ }^{30}$, lecz sprowadza się do indywidualnego kaprysu i przebieranki. Powtórzmy, że odrzucając dobra materialne i pozory kolonialnego prestiżu, szukając powrotu do natury, Gauguin odwraca wprawdzie kierunek eurocentrycznego mitu rozwoju od natury do cywilizacji, jednak nie niweczy eurocentrycznej matrycy tego mitu, którą tworzy relacja władzy ${ }^{31}$.

Ta i inne trafne krytyczne intuicje na temat kolonialnego świata mieszczą się tutaj w ramie powieści niosącej zakorzenione w europejskiej nowoczesności przesłanie o sztuce, która usprawiedliwia słabości i osłabia wymowę niepowodzeń. Gauguin umiera w nędzy, z ciałem wyniszczonym syfilisem, nie do końca jeszcze uznany w Europie; jednak świetność jego dzieła nadaje ostatecznie sens całemu jego życiu.

\footnotetext{
${ }^{29}$ H.K. Bhabha, Of Mimicry and Man..., dz. cyt., s. 132.

30 Tenże, Location of Culture, dz. cyt., s. 142-145.

31 A. Quijano, Colonialidad del poder..., dz. cyt., s. 211.
} 


\section{Drakońskie ćwiczenia z empatii i identyfikacji. Marzenie Celta}

Kolejny bohater, także wzorowany na postaci historycznej, Roger Casement z Marzenia Celta, przeżywa jeszcze bardziej spektakularne przemiany: od skromnego urzędnika, poprzez autora poruszających raportów o nadużyciach w Kongo i w Amazonii (w powieści Joseph Conrad nazywa go „brytyjskim Las Casasem"), do irlandzkiego patrioty uwięzionego przez Brytyjczyków. Urzeczony przygodami słynnych eksploratorów jedzie pierwszy raz do Afryki w 1884 roku jako członek ekspedycji Henry’ego Mortona Stanleya. Przez lata przyglądania się stopniowej eksterminacji Afrykańczyków - opustoszałym wioskom, splądrowanym lasom, okaleczonym bestialsko dzieciom i dorosłym - traci wiarę w europejską misję w koloniach: w zapewnienia, że gdy Afryka otworzy się na handel, wtedy niewolnictwo zniknie, a ochrzczeni mieszkańcy wzniosą się na wyższy poziom cywilizacji ${ }^{32}$. Przebudzony niczym młody Budda, bohater nabywa bolesną wiedzę: „gdyby miał podać jedno słowo, które leżało u źródła tych wszystkich okropieństw, brzmiałoby ono: zachłanność. Żądza zysku"33. W pierwszej dekadzie XX wieku rząd brytyjski zleca mu sporządzenie raportów o łamaniu praw człowieka w Kongo Belgijskim, następnie o działalności brytyjskich przedsiębiorstw przemysłu kauczukowego w peruwiańskiej Amazonii. Podczas obu misji Casement kataloguje okrucieństwa z rzetelnością angielskiego urzędnika.

Powieść rejestruje równie skrupulatnie fizyczne i psychiczne ślady zniszczenia, jakie zostawia na bohaterze długotrwały kontakt ze złem. W apokaliptycznej scenerii, prefigurującej obozy koncentracyjne XX wieku, Casement widzi na twarzach tubylców „zastygły grymas wyrażający nie tyle ból, ile bezkresne zdumienie tym, co się z nimi dzieje" 34 . Ból innych przekłada się na jego własne doznania. W Kongu „[p]rawie nie sypiał, a gdy powalało go zmęczenie, nadchodziły koszmary, w których przechodził od trwogi do osłupienia, od satanicznych wizji do przygnębienia i smutku, kiedy wszystko traciło sens i rację bytu”"35; w Amazonii, „, [b]ył zlany potem, bolało go całe ciało, czuł odrętwienie, które przesuwało się od narządu do narządu, od stóp do głów. Kongo. Amazonia. Czyż ludzkie cierpienie nie ma granic?”36; „zmęczenie i niepokój nie

32 M. Vargas Llosa, Marzenie Celta, dz. cyt., s. 42, 48.

33 Tamże, s. 89.

${ }^{34}$ Tamże. Achille Mbembe cytuje Fanona, mówiąc, że tworzące się człowieczeństwo jest rezultatem spotkania z „twarzą innego”, który poza tym „odkrywa mnie dla mnie samego”. A. Mbembe, Polityka wrogości, tłum. U. Kropiwiec, Kraków 2018, s. 182. I ciągnie dalej: „Zatem człowieczeństwo jest tylko tam, gdzie ten gest - relacja troski - jest możliwy; gdy dajemy się wzruszyć twarzą innego; gdy ten gest wiąże się ze słowem, mową, zdolną przełamać milczenie" (tamże).

${ }^{35}$ M. Vargas Llosa, Marzenie Celta, dz. cyt., s. 88.

36 Tamże, s. 156. 
pozwalały mu pracować nad (...) obmyślaniem zarysów raportu. Spał mało, dręczyły go koszmary" ${ }^{37}$. Powieść nie przedstawia doświadczenia kolonizacji oczami mieszkańców podbitych regionów, lecz z zewnętrznej perspektywy Europejczyka ${ }^{38}$. Próbuje on wprawdzie racjonalizować zło, dociekając jego korzeni moralnych (o czym świadczy poprzedni cytat o żądzy zysku), ale to, co się dzieje w koloniach, mimo umocowania w racjonalnym dyskursie o modernizacji - nie jest do łatwe do zrozumienia. Władza kolonialna zaciera bowiem tropy przemocy, uciekając się do typowych dla ideologii „naturalizacji” swych opresyjnych działań, w związku z czym tubylcy, z ich wyglądem i sposobem bycia, żyjący w biedzie i poniżeniu, stają się „przyczyną i skutkiem” systemu, uwięzieni, jak pisze Bhabha, w błędnym kole interpretacji ${ }^{39}$.

To doświadczenie przynosi Casementowi szok moralny i poznawczy: jak zrozumieć skalę krzywd? Jak zaakceptować to, że nikt nie zamierza im zadośćuczynić? Przeżywa on cierpienie odciśnięte na ciałach tubylców jako klęskę europejskiego projektu cywilizacyjnego, ale też jako dramat osobisty - cierpi, somatyzuje, a później odkrywa własną kolonialną kondycję, Irlandczyka podległego władzy brytyjskiej, uosabiając w ten sposób konflikty i sprzeczności kolonializmu. Ich ukoronowaniem jest fakt, że właśnie w upiornych warunkach kolonialnych Casement doznaje swoistego wyzwolenia. Znamienna jest scena jego coming outu, gdy uświadamia sobie własne pożądanie na widok kąpiących się młodych Afrykańczyków. Scena niemego rozpoznania i akceptacji bohatera przez czarnego chłopca przynosi reminiscencje słów Jeana-Paula Sartre'a o spojrzeniu, które Afrykanin „oddaje” białemu człowiekowi, występującemu tym razem w niezwykłej dla siebie roli oglądanego, podporządkowanego; a jednocześnie odnajduje się on w cudzych oczach: „Dzisiaj ci czarni ludzie patrzą na nas i nasze spojrzenie powraca nam w oczy" ${ }^{40}$. Scena zdaje się także powtórzeniem, choć odwróconym, powszechnej w społeczeństwie skolonizowanym potrzeby akceptacji przez „Pana” ${ }^{11}$ - w tym wypadku Panem odpowiadającym milcząco na pożądanie seksualne Białego jest właśnie tubylec ${ }^{42}$.

W obrębie powieści dużo miejsca zajmują rozmowy, spory, sesje komisji, podczas których postacie komentują nadużycia i wyzysk w koloniach, przejawiając cały wachlarz różnych postaw: od szczerej chęci pomocy mieszkańcom kolonii, poprzez obojętność i konformizm, po zakłamanie i zimne okrucieństwo. Dyskursy humanitarne, jak poniższy, brytyjskiego misjonarza z Konga, nie brzmią dzisiaj przekonująco:

37 Tamże, s. 246.

38 S. Cadera, Mario Vargas Llosa y la temática postcolonial, „Antípodas. Journal of Hispanic and Galician Studies" 2016, nr 26, s. 52-53.

${ }^{39}$ H.K. Bhabha, Location of Culture, dz. cyt., s. 83.

40 J.-P. Sartre, Czarny Orfeusz, tłum. W. Leopold, „Przegląd Socjologiczny” 1969, t. 23, s. 388 .

${ }^{41}$ F. Fanon, Piel negra, máscaras blancas, dz. cyt., s. 175-183.

42 Podobną akceptację czuł Gauguin w towarzystwie biseksualnego mahu na Tahiti. 
przynajmniej w teorii, sprawa „cywilizacji” była słuszna. Czyż warunki życia tubylców nie były straszne? (...) A poza tym czyż nie było dla nich dobre poznanie prawdziwego Boga, zastąpienie bożków, których wielbili, Bogiem chrześcijańskim, Bogiem litości, miłości i sprawiedliwości? (...) Ze Starego Kontynentu nadeszły przecież także dobre rzeczy. Nie tylko zachłanność handlarzy o brudnej duszy, lecz także nauka, prawodawstwo, edukacja, przyrodzone prawo istoty ludzkiej, etyka chrześcijańska. A ponadto, czyż nie było zbyt późno, by się wycofać? ${ }^{43}$

Bardziej przejmujące niż zacytowane, dziś niepoprawne politycznie poglądy misjonarza, jest to, że ginęły one w morzu już to bezrefleksyjnego rasizmu, już to zimnego pragmatyzmu oraz „zwykłej”, bezinteresownej żądzy krwi. Siejący postrach kapitan Massard z Force Publique, służby porządkowej w Kongu, mówi w odpowiedzi na raportowane przez Casementa setki aktów przemocy: „Ci okaleczeni ludzie nie będą już zdolni do pracy albo będą wykonywać ją źle, a ich wydajność będzie minimalna" ${ }^{4}$. Massard uosabia perwersję prawa kolonialnego, jest mordercą, który włączył zabijanie do repertuaru usankcjonowanych zachowań „cywilizowanego” człowieka, pracując w ten sposób na rzecz nekropolityki, która nadal funkcjonuje w dzisiejszym świecie. Okrucieństwo jednostkowe, przemoc systemowa, pokłady ludzkiego sadyzmu - wszystko to, co wstrząsa systemem nerwowym i moralnym Casementa, było konsekwencją upowszechnienia odczuwalnej do dziś formy sprawowania suwerenności, polegającej na „uogólnionej instrumentalizacji ludzkiego istnienia i materialnym zniszczeniu ciał i populacji ludzkich" ${ }^{45}$.

Inne postacie usprawiedliwiają swój współudział w zbrodniczej eksploatacji wrodzonymi rzekomo przywarami tubylców: niesumiennością, niechęcią do pracy, brutalnością, niedorozwojem: „na poziomie umysłowym bliżej im do krokodyla i hipopotama (...). Dlatego to my decydujemy za nich, wybieramy to, co jest dla nich dobre, podsuwamy im te umowy" ${ }^{46}$.

Kluczowe są tu właśnie „te umowy”, gorsze chyba w ostatecznym rozrachunku od najgorszych rasistowskich stereotypów („dwunożne istoty barwy hebanu" ${ }^{\prime 47}$ ). Teoretycy z dawnych terytoriów zależnych nieustannie przypominają, że dzisiejsza mapa hegemonii na świecie nie uległa zasadniczej zmianie od czasów kolonialnych. „Dopiero ostatnio zaczęliśmy sobie zdawać sprawę ze związanych z "polowaniem na ludzi« metabolizmów ekologicznych (materia,

${ }_{43}$ M. Vargas Llosa, Marzenie Celta, dz. cyt., s. 60.

${ }_{44}$ Tamże, s. 83.

45 A. Mbembe, Nekropolityka [w:] tegoż, Polityka wrogości, dz. cyt., s. 211. Utrwalone w kolonializmie relacje wrogości, nigdy dogłębnie nieprzepracowane, przynoszą w naszych czasach rezultaty w postaci polityki radykalnej wrogości. Inny to już nie ten, wobec którego umacniam swoje ja, lecz ten, którego należy zabić.

46 Tamże, s. 40.

47 Tamże, s. 50. 
energia), bez których handel atlantycki nie byłby możliwy”48. Latynoamerykańska filozofia dekolonialna kwestionuje mit europejskiego postępu i rozwoju (chrystianizacji, cywilizowania, uprzemysłowienia, alfabetyzacji), odsłaniając ukryte oblicze modernizacji ${ }^{49} \mathrm{i}$ dostrzegając ciągłość „negatywności” (braku praw, głosu w przestrzeni publicznej i środków do życia) między niegdysiejszym Indianinem tracącym zdrowie i życie w kopalni srebra a dzisiejszym nielegalnym emigrantem ze światowego Południa ${ }^{50}$.

W Marzeniu Celta mamy więc po jednej stronie złowieszczy system prowadzący do destrukcji ludzi i świata, po drugiej białego bohatera, który przybywa z zewnątrz i szuka sprawiedliwości, ale jest skazany na klęskę w nierównej walce. Rozmówcy w Afryce i w Ameryce przekonują Casementa, że niewiele można zrobić: „To, do czego jesteśmy zmuszani, godzi w moje zasady. - Dotknął medalika na szyi. - W moją wiarę. (...) Jednakże (...) obawiam się, że nie osiągnie pan niczego. Żadna ludzki siła nie zmieni tego systemu. Za późno na to" ${ }^{\text {1. }}$.

Wielu pracowników firm, którym Casement w raportach przypisywał najgorsze zbrodnicze nadużycia, nie popierało okrucieństw, ale drżąc o posadę, dorzucało cegiełkę banalnego zła do prosperującego sytemu, który łączył odciętą rękę Afrykańczyka czy zgwałconą i zabitą żonę amazońskiego kacyka z błyszczącymi posadzkami londyńskiej siedziby firmy należącej do potentata kauczukowego.

Spotkanie z tubylcami ze światów kolonialnych powoduje u Casementa traumę, którą przepracowuje przez pisemne świadectwo, działanie w polityce i takie, które dziś nazwałoby się aktywizmem. Tubylcy pojawiają się też indywidualnie w jego życiu prywatnym: dwaj chłopcy, amazońscy Indianie, którzy zostają jego służącymi i których ratuje od możliwej śmierci, transportując do Anglii. Inni to partnerzy przygodnych kontaktów seksualnych

Mimo jego obiektywnej słabości w walce ze złem i pomimo bardzo ludzkich nawyków i odruchów, o które Vargas Llosa przykładnie uzupełnia wizerunek (żądze cielesne, intymne fantazje seksualne), Casementowi nie odmawia się jednak w powieści aury heroizmu. To bohater z tradycji europejskiej, usiłujący w serii przygód przekuć swoje wartości i przekonania, czyli życie wewnętrzne, w czyny ${ }^{52}$. Ludzie tacy jak on (wyznaje jeden z przygodnych rozmówców) przynoszą „ulgę i nadzieję” i należy modlić się, „by Bóg pozwolił [mu - N.P.] uczynić coś dla tych nieszczęsnych istot" ${ }^{\prime 3}$.

48 A. Mbembe, Polityka wrogości, dz. cyt., s. 167.

49 „[Ś]wiat kolonialny na peryferiach, zgładzony w ofierze Indianin, zniewolony Czarny, uciskana kobieta, wyalienowane dziecko, kultura ludowa itp. („ofiary Nowoczesności”) jako ofiary czynów irracjonalnych, jako zaprzeczenie nowoczesnego ideału racjonalności”. E. Dussel, Hacia una filosofía politica critica, dz. cyt., s. 355 [tłum. własne - N.P.].

50 Tamże, szczególnie rozdz. 7: Derechos humanos y ética de la liberación.

51 M. Vargas Llosa, Marzenie Celta, dz. cyt., s. 97.

52 G. Lukács, Teoria powieści, tłum. J. Goślicki, posłowie A. Brodzka, Warszawa 1968, s. 93.

53 M. Vargas Llosa, Marzenie Celta, dz. cyt., s. 102. 
Przyszłość pokazała, że niewiarygodne pokłady wysiłku w zwalczaniu niesprawiedliwości, jakie ofiarował światu Casement (także liczne inne postacie z powieści Vargasa Llosy), nie przestawiły polityki globalnej na inne tory. Żadnemu zresztą z wykreowanych przez autora zapaleńców, poszukiwaczy prawdy, rewolucjonistów i obrońców uciśnionych nie udaje się wcielić w życie własnego projektu utopii: czy to raju artystów, o jakim marzył Gauguin, czy to świata, w którym zyski jednych nie przysparzają cierpienia drugim, jak chciałby Casement. Vargas Llosa, który tyle pięknych myśli poświęcił wyobraźni i kompensacyjnej roli alternatywnych światów literackich ${ }^{54}$, znany jest publicznie jako obrońca ekonomii liberalnej. Oddziela wtedy grubą kreską wizje świata kreowane w głowach swych postaci od tych, które popiera jako komentator czy polityk (startował w wyborach prezydenckich w Peru w roku 1990). O ile w twórczości artystycznej utopia jest uprawniona i inspirująca, dowodzi Vargas Llosa, o tyle w sferze społecznej:

przyniosła nam tylko barbarzyństwo. Utopia nigdy nie zaowocowała postępem. Ciągną się za nią ciżba trupów, tłum torturowanych, wszyscy przegrani w wojnach religijnych, wszyscy zamordowani w czystkach, wywiezieni do obozów koncentracyjnych przez rewolucje ${ }^{55}$.

Narrator Marzenia Celta piętnuje wynaturzenia kapitalizmu, z kolei Vargas Llosa polityk uznaje, że kapitalizm jest jedyną alternatywą, by zwalczyć biedę ${ }^{56}$. Idee, z których zrodziły się poruszające losy jego postaci, przedstawia on ostatecznie jako społecznie nieaplikowalne.

Na pierwszym planie w omówionych tu powieściach sytuują się zatem, powtórzmy, spektakularne przemiany głównych bohaterów: $\mathrm{z}$ finansisty w artystę; z urzędnika w samotnego sprawiedliwego. Raj tuż za rogiem i Marzenie Celta przedstawiają je sugestywnie, posiłkując się faktami biograficznymi i technikami monologu wewnętrznego wypracowanymi na gruncie europejskiego realizmu, w związku z czym: „»autentyczność« przysługuje kategoriom doświadczenia autoryzowanym przez centrum kosztem tych, którzy zostali zepchnięci

${ }^{54}$ Między innymi w trzech tomach Contra viento y marea (1983-1990), Prawdzie ktamstw (1990; wyd. pol. 1999, tłum. M. Lewicka), a także w artykułach publikowanych w hiszpańskim dzienniku „El País”. W 2017 roku ukazał się w polskim przekładzie wybór tekstów pod tytułem O literaturze i pisaniu (tłum. T. Pindel).

55 Rozmowa D. Gallaghera z Vargasem Llosą z 20 sierpnia 1989 roku (w trakcie prezydenckiej kampanii wyborczej) w Centro de Estudios Públicos w Santiago de Chile, „Estudios Públicos" 1989, nr 36, https://cs.uwaterloo.ca/ -alopez-o/politics/mario.html, dostęp: 24.07.2019.

56 Wśród polskich badaczy Urszula Ługowska podkreśla prawicowo-liberalny wydźwięk przekonań politycznych Vargasa Llosy, wyczytując je zresztą także z powieści (Mario Vargas Llosa. Literatura, polityka i Nobel, Warszawa 2012). Tomasz Pindel odnotowuje ewolucję jego poglądów (odwrót od poparcia dla lewicy w latach siedemdziesiątych), ale sytuuje pisarza bardziej w centrum i podkreśla, że miernikiem sympatii politycznych jest dla niego wolność słowa i działań artystycznych (Mario Vargas Llosa. Biografia, Kraków 2014). 
na margines Imperium" ${ }^{57}$. Spotkania bohaterów z rdzennymi mieszkańcami na peryferiach Imperium, jakkolwiek kluczowe dla ich rozwoju, nie zmieniają ostatecznie zasadniczej relacji kolonizowany-kolonizujący. Gauguin przyjaźni się z tubylcami, ale potrzebuje ich do rozładowywania energii seksualnej i twórczej, do eksplorowania przestrzeni sztuki powołanej na własnych warunkach. Casement z kolei odkrywa dzięki kontaktom z tubylcami swoją misję moralną, a później polityczną, a przy okazji - swoją seksualność, przeklętą i wypartą część tożsamości.

W Marzeniu Celta jest wzmianka, o tym, że w Afryce Casement odwiedzał wioski, w których widział, jak lokalne tańce, obrzędy i „niewinność prymitywna, zdrowa (...) mieszała się z okrutnymi zwyczajami”, a wtedy czuł „trudny do zdefiniowania dyskomfort, poczucie, że stosuje brudne zagrywki wobec tych ludzi z innej epoki, którzy choćby nie wiem jak się starali, nie zrozumieją go całkowicie" 58 . Tubylcy nie muszą rozumieć Casementa, wystarczy, że robią to czytelnicy powieści. On sam ma nieczyste sumienie, bo początkowo namawia Afrykańczyków na zgubne dla nich kontrakty handlowe. Ale wyciąga z tego wnioski: odrzuca wspólnictwo w wyzysku, po czym uczciwie i racjonalnie przechodzi do działania.

I Gauguin, i Casement wywodzą się ze świata „brudnych zagrywek” i mimo że na pewnym etapie odmawiają w nim uczestnictwa, nie potrafią, niczym bohaterowie tragiczni w obliczu fatum, zmienić biegu dziejów podporządkowanego bożkowi Mamonowi. Powieści Vargasa Llosy nie są, częstym skądinąd w literaturze postkolonialnej, radykalnym przepisaniem historii na nowo z perspektywy uciśnionych. To raczej historie pisane dla Białych i o Białych, o takich jednak, którzy w swoim czasie, wiek temu z okładem, odkryli niszczącą moc europejskiego imperializmu. Widzimy na ich przykładzie, jak na przełomie XIX i XX wieku rodziła się europejska myśl (samo)krytyczna w odniesieniu do kolonializmu i jakie były jej nieuchronne ograniczenia. Z perspektywy XXI wieku Vargas Llosa przełamuje oczywiście eurocentryzm w swej powieściowej ocenie przemocy jako uprawomocnienia kolonializmu, nie porzuca jednak takiej perspektywy białego bohatera, do której nawykliśmy w tradycji nowoczesnej powieści europejskiej; stąd niejaka ambiwalencja tych utworów, której korzenie tkwią w kolonialnych i postkolonialnych uwarunkowaniach literatury hispanoamerykańskiej.

Literatura, która przenosi pamięć o mieszkańcach kolonii, stosuje różne sposoby rozsadzenia od wewnątrz europejskich konwencji, odzyskania reprezentacji, jak nazywa to Mroczkowska-Brandt, co dokonuje się często za sprawą nietypowych technik narracyjnych. Omówione powieści Vargasa Llosy, które traktują o kolonialnej przemocy, są wszakże (mimo gry planami przestrzennymi i czasowymi) stosunkowo tradycyjne, nawet na tle jego całej twórczości - co nie

\footnotetext{
57 B. Ashcroft, G. Griffiths, H. Tiffin, dz. cyt., s. 90.

58 M. Vargas Llosa, Marzenie Celta, dz. cyt., s. 58.
} 
znaczy, że nie poraża w nich czytelnika okrucieństwo opisywanego świata. Przy okazji rozważań o literaturze postkolonialnej wraca więc zawsze aktualne pytanie o skuteczność i granice fikcji literackiej w zetknięciu z ludzkim cierpieniem.

\section{Bibliografia}

Anderson B., Wspólnoty wyobrażone. Rozważania o źródtach i rozprzestrzenianiu się nacjonalizmu, tłum. S. Amsterdamski, Kraków 1997.

Ashcroft B., Griffiths G., Tiffin H., The Empire Writes Back. Theory and Practice in Post-Colonial Literatures, London-New York 1989.

Bhabha H.K., Location of Culture, London-New York 1994.

Bhabha H.K., Of Mimicry and Man: The Ambivalence of Colonial Discourse, „October" 1984, nr 28, www.jstor.org/stable/778467, dostęp: 24.07.2019.

Cadera S.M., Mario Vargas Llosa y la temática postcolonial, „Antípodas. Journal of Hispanic and Galician Studies" 2016, nr 27.

Dussel E., Hacia una filosofia politica crítica, wprowadzenie E. Mendieta, Bilbao 2001.

Fanon F., Piel negra, máscaras blancas [oryg. Peau noire, masques blanches, 1952], tłum. na hiszp. A. Useros Martín, Madrid 2009.

Fanon F., Wyklęty lud ziemi [1961], tłum. H. Tygielska, przedmowa E. Rekłajtis, posł. J.-P. Sartre, Warszawa 1985.

Kokotovic M., Vargas Llosa in the Andes: The Racial Discourse of Neoliberalism, "Confluencia” 2000, nr 2, www.jstor.org/stable/27922749, dostęp: 20.06.2019.

López-Calvo I., El anti-indigenismo en "El hablador" y "Lituma en los Andes”, de Mario Vargas Llosa, „Desde el Sur” 2009, nr 2.

Lukács G., Teoria powieści, tłum. J. Goślicki, posłowie A. Brodzka, Warszawa 1968. Ługowska U., Mario Vargas Llosa. Literatura, polityka i Nobel, Warszawa 2012.

Łukaszyk E., Od podlegtości do horyzontalnego diagramu relacji. Studium relacji transkolonialnych [w:] Debaty Artes Liberales, t. 10: Perspektywy postkolonializmu w Polsce, Polska w perspektywie postkolonialnej, red. J. Kieniewicz, Warszawa 2016.

Mbembe A., Polityka wrogości, tłum. U. Kropiwiec, K. Bojarska, Kraków 2018.

Mignolo W.D., Historias locales/diseños globales. Colonialidad, conocimientos subalternos y pensamiento fronterizo, tłum. na hiszp. J.Mª Madariaga, C. Vega Solís, Madrid 2003.

Mignolo W.D., The Darker Side of the Renaissance. Literacy, Territoriality, and Colonization, Ann Arbor 1995.

Mroczkowska-Brand K., Postkolonialna lekcja uważności, „Konteksty Kultury” 2019, nr 3 .

Ortiz Rodríguez $\mathrm{M}^{2}$. de las M., La fisura irremediable: indigenas, regiones y nación en tres novelas de Mario Vargas Llosa, „Antípoda: Revista de Antropología y Arqueología” 2012, nr 15, http://dialnet.unirioja.es/descarga/articulo/4085 032.pdf 2012, dostęp: 21.06.2019. 
Pindel T., Mario Vargas Llosa. Biografia, Kraków 2014.

Piñeyro J.C., La construcción de la alteridad en „Lituma en los Andes”, „Studia Neophilologica” 2014, nr 2.

Quijano A., Colonialidad del poder, eurocentrismo y América Latina [w:] La colonialidad del saber: eurocentrismo y ciencias sociales. Perspectivas latinoamericanas, red. E. Lander, Buenos Aires 2000, http://bibliotecavirtual.clac-so.org.ar/ar/ libros/lander/quijano.rtf, dostęp: 17.06.2019.

Rodríguez J.C., De qué hablamos cuando hablamos del marxismo, Madrid 2013.

Rozmowa D. Gallaghera z Vargasem Llosą z 20 sierpnia 1989 roku (w trakcie prezydenckiej kampanii wyborczej) w Centro de Estudios Públicos w Santiago de Chile, „Estudios Públicos” 1989, nr 36, https://cs.uwaterloo.ca/ alopez-o/politics/mario.html, dostęp: 24.07.2019.

Sartre J.-P., Czarny Orfeusz, przeł. W. Leopold, „Przegląd Socjologiczny” 1969, t. 23.

Vargas Llosa M., La orgía perpetua. Flaubert y „Madame Bovary”, Barcelona 1975.

Vargas Llosa M., Marzenie Celta, tłum. M. Chrobak, Kraków 2016.

Vargas Llosa M., Raj tuż za rogiem, tłum. D. Rycerz, Kraków 2010. 